\title{
A COMPARATIVE STUDY OF PAPER FILLERS
}

\author{
By Merle B. Shaw and George W. Bickir
}

\section{ABSTRACT}

Fillers, as the term is used in the paper industry, are finely divided substances added to paper to fill up the spaces between the fibers composing the sheet and to give certain physical characteristics (opacity, body, finish) to the paper produced. Commercial paper fillers, including asbestine, talc, clay, crown filler, and gypsum, were studied to determine their comparative paper-making values. The tests were made in the semicommercial paper mill of the bureau. The percentage of filler added was varied, the amount being 10 and 20 per cent, by weight, of the beater furnish. The paper produced was tested for weight, strength, color, opacity, finish, degree sized, and filler retention.

Asbestine, talc, and clay were found to have similar paper-making properties. Crown filler and gypsum, being soluble in water, yielded somewhat different results from the other insoluble fillers.

Retention was considerably less for the soluble materials, and, in general, the differences noted in the characteristics of the papers were due chiefly to the difference in the amount of filler retained. One of the clays and one of the gypsum samples were low in brightness, however, and the papers containing these materials were correspondingly dull. Paper containing the other gypsum and clay samples compared favorably in this respect with that containing the other fillers. The sizing process and the other paper-making operations were not adversely affected by any of the fillers employed

\section{CONTENTS}

I. Introduction.

II. General characteristics of paper fillers

III. Description of materials used.

1. Pulps

2. Fillers

(a) General description and source

(b) Chemical analyses

(b) Chemical analyses_-_-_-

(c) Grit determinations

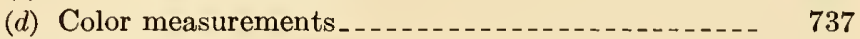

IV. Paper-making equipment used.

V. Description of methods used. 740

1. Adding filler.-_- 740

2. Machine observations and sampling

3. Determining percentage of ash due to filler._. 740

4. Determining retention... 740

VI. Tabulation and discussion of test results

1. Solid material in paper and machine water samples._._. 742

2. Filler content of samples..._. 742

3. Measurements on finished paper. 743

VII. Summary and conclusions _. 746

VIII. Bibliography 


\section{INTRODUCTION}

Fillers, as the term is used in the paper industry, are finely divided substances added to paper to fill up the spaces between the fibers composing the sheet. The fibers composing paper lie in a tangled mat separated by relatively large spaces. If a smooth, compact surface is desired, the interstices need to be filled. A good filler has sufficient range of particle sizes to fill the voids, and at the same time it gives the sheet certain physical characteristics (opacity, body, finish) especially desirable in some grades of paper. Fillers have come to be regarded as a necessary constituent of some papers, particularly book, for improvement of printing quality.

A comparison of American and foreign clays as paper fillers has previously been published. ${ }^{1}$ Similar work on other fillers has recently been completed, and the data obtained are presented in this paper. The reader is referred to the earlier publication for the data on comparison of clays and for various details of test procedure common to both investigations.

\section{GENERAL CHARACTERISTICS OF PAPER FILLERS}

The fundamental characteristics of paper fillers are good white color; low content of grit, mica, and other impurities; low solubility in water; freedom from chemical action with alum or effect on sizing; uniform quality; gradation of particles; and low cost.

The fillers used in this investigation were asbestine, talc, clay, crown filler, and gypsum.

Asbestine (or agalite) is a fibrous variety of talc, so called because of its close mineralogical similarity to asbestos. Its largest use is in the paper industry.

Talc is a hydrated magnesium silicate whose most striking characteristics are extreme softness, pearly luster, and soapy feel. It is of silvery white, gray, or pale green color, is free from excessive grit, and is very resistant to acids and solutions of alkali. It occurs in veins and surface outcroppings and in the United States is found chiefly in a belt in the Appalachian mountains, from Canada to Alabama. The use to which it is put varies according to its purity and physical characteristics. The largest uses are in powdered form as toilet powders, adulterants, and fillers.

Clays differ greatly in both mineral and chemical composition, but all are alumina silicates with varying quantities of other minerals. They are natural substances derived from the weathering and disintegration of rocks and minerals and are found in all parts of the world as residual beds or transported.deposits. The peculiar properties

1 B. S. Tech. Paper No. 262. 
common to all clays are plasticity when wet and coherence when dry. Clays are the most used paper fillers.

Crown filler is an artificially prepared calcium sulphate (also called sulphate of lime and artificial gypsum). When properly prepared, it is white, free from grit and dirt, and uniform in quality.

Gypsum is a natural calcium sulphate characterized by softness and a snowy white color when pure. It is a sedimentary deposit occurring (frequently in beds of considerable thickness) in many parts of the United States as well as other parts of the world. It is found in veins by itself or in association with other minerals. After being pulverized either the raw or the calcined product may be used as a filler.

\section{DESCRIPTION OF MATERIALS USED}

\section{PULPS}

Equal parts of sulphite and soda pulps were used for the papermaking tests.

\section{FILLERS}

Preliminary tests were made on 24 commercial paper fillers. The fillers were compared as to chemical analysis, color, feel, and cost and, considering these properties, 8 representative samples were selected for the paper-making tests.

(a) General Description and Source.-The source of each filler selected and the description given were as follows:

Asbestine.-Mined in New York. "** * * is extensively used as filler in paper, such as, book, writings, envelope, bristols, posters, blotting, insulating, roofing, building, box board, etc., in which is secured an even, opaque sheet."

Talc.-Mined in New York.

Clay No. 1.- Mined in South Carolina. (This clay is the No. 4 used in "Comparison of American and foreign clays as paper fillers." 2

Clay No. 2.- Mined in Vermont. Graded as a "No. 3" clay by company supplying.

Clay No. 3.- Mined in Georgia. "This clay is subjected to a refined washing process. * * *."

Crown filler._"**** freedom from grit, dirt, and other impurities make crown filler the highest grade of filler available * * *."

Gypsum No. 1.-Mined in Oklahoma. "This material is a deadburned gypsum that has practically all of the water of crystallization removed and will set only very slowly."

Gypsum No. 2.- Mined in Ontario, Canada. This is very finely ground gypsum. Mechanical analyses made at the bureau show 79

\footnotetext{
2 B. S. Tech. Paper No. 262.
} 
per cent of this sample to be particles whose average diameter is 0.01 mm or less' and 92 per cent $0.02 \mathrm{~mm}$ or less. For gypsum No. 1 the corresponding fineness was 21 per cent and 64 per cent, respectively. ${ }^{3}$

Asbestine, talc, clay No. 1, clay No. 2, and gypsum No. 1 were approximately the same price. The comparative price of each of the other fillers was: Gypsum No. 2, one-third more; clay No. 3, onehalf as much; and crown filler, more than twice as much.

(b) Chemical Analyses.--The following analyses show the chemical composition of the 8 fillers selected:

TABLE 1.-Chemical analyses of fillers

\begin{tabular}{|c|c|c|c|c|c|c|c|c|}
\hline Constituents & $\begin{array}{l}\text { Asbes- } \\
\text { tine }\end{array}$ & Talc & $\begin{array}{l}\text { Clay } \\
\text { No. } 1\end{array}$ & $\begin{array}{l}\text { Clay } \\
\text { No. } 2\end{array}$ & $\begin{array}{l}\text { Clay } \\
\text { No. } 3\end{array}$ & $\begin{array}{c}\text { Crown } \\
\text { filler }\end{array}$ & $\begin{array}{l}\text { Gyp- } \\
\text { sum } \\
\text { No. } 1\end{array}$ & $\begin{array}{l}\text { Gyp- } \\
\text { sum } \\
\text { No. } 2\end{array}$ \\
\hline $\begin{array}{l}\text { Magnesium o } \\
\text { Alkalies as so }\end{array}$ & $\begin{array}{r}\text { Per cent } \\
63.00 \\
.15 \\
.59 \\
4.19 \\
28.26 \\
\text { Trace. }\end{array}$ & $\begin{array}{r}P \text { Per cent } \\
55.50 \\
.10 \\
1.32 \\
6.20 \\
32.00 \\
\text { Trace. }\end{array}$ & $\left|\begin{array}{r}P e r \text { cent } \\
45.70 \\
.40 \\
40.49 \\
\text { Trace. } \\
.10 \\
.36\end{array}\right|$ & $\mid \begin{array}{r}\text { Per cent } \\
51.58 \\
1.10 \\
34.10 \\
\text { Trace. } \\
.34 \\
.18\end{array}$ & \begin{tabular}{|} 
Percent \\
43.04 \\
.70 \\
42.00 \\
Trace. \\
.08 \\
.15
\end{tabular} & $\mid \begin{array}{c}\text { Per cent } \\
0.11 \\
\text { Trace. } \\
.08 \\
32.01 \\
\text { Trace. }\end{array}$ & $\mid \begin{array}{c}\text { Per cent } \\
0.32 \\
\text { Trace. } \\
.05 \\
40.99 \\
.10\end{array}$ & $\begin{array}{r}\text { Per cent } \\
0.37 \\
.02 \\
.11 \\
32.62 \\
.15\end{array}$ \\
\hline $\begin{array}{l}\text { cidity as hydr } \\
\text { ciditised }\end{array}$ & $\begin{array}{r}\text { Trace. } \\
.28 \\
3.87 \\
.63\end{array}$ & $\begin{array}{r}\text { Trace. } \\
.56 \\
4.59 \\
1.27\end{array}$ & $\begin{array}{l}\text { Trace. } \\
\text { None. } \\
13.04\end{array}$ & $\begin{array}{r}\text { Trace. } \\
.07 \\
11.89 \\
.17\end{array}$ & $\begin{array}{r}\text { Trace. } \\
\text { None. } \\
13.45\end{array}$ & $\begin{array}{r}45.76 \\
.13 \\
122.09 \\
.29 \\
\text { Trace. }\end{array}$ & $\begin{array}{r}58.48 \\
\text { None. } \\
1.06\end{array}$ & $\begin{array}{r}45.54 \\
1.70 \\
119.40 \\
1.59\end{array}$ \\
\hline
\end{tabular}

1 Determined at $225^{\circ} \mathrm{C}$. By strong ignition, calcium sulphate loses $\mathrm{SO}_{3}$.

(c) Grit Determinations.--Table 2 gives the grit content of the fillers and Figure 1 shows diagrammatically a cross sectional view of the apparatus used in the determinations.

A No. 200 sieve, 3 inches in diameter and $11 / 2$ inches high, was used for screening the fillers. The sieve rested on a 10-mesh screen which was suspended by hooks from the edge of a water container and so adjusted that the height of water in the sieve was 1 inch.

A $100 \mathrm{~g}$, bone-dry, sample of filler (sometimes $50 \mathrm{~g}$, the amount depending on the ease with which the material screened) was made into a slip by mixing with water and allowed to stand several hours, being agitated at intervals to insure "wetting" of all the particles. It was then poured slowly into the sieve, filled with water, as shown in the diagram. Meanwhile a gentle stream of water was also being run into the sieve. The downward flow of the water carried the fine particles of filler through the wire cloth and over the edge of the dish. Water was added until that overflowing from the receptacle was as clear as that entering the sieve. By this method there was no forcing or brushing of the particles, and the results obtained were very satisfactory.

\footnotetext{
3 The Pearson air separator, developed by J. C. Pearson and F. A. Hitchcock, Bureau of Standards, was used in making these determinations.
} 
The percentage of the material that remained in the sieve was determined after drying and weighing. For some of the fillers not all of the residue was grit, however. Asbestine and talc left considerable fiber after separation, and the principal constituent of the residue for gypsum No. 1 was gypsum particles, not sufficiently crushed to pass

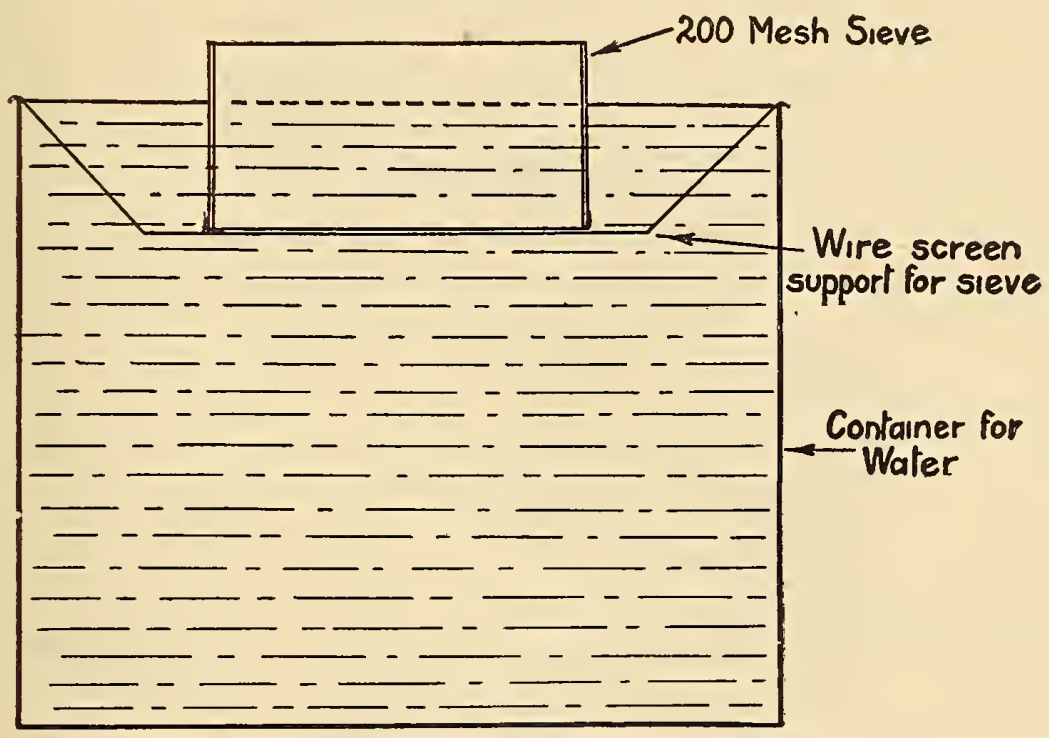

FIG. 1.-Apparatus used in determining grit content of fillers

through the sieve cloth. The grit content of this sample was probably no higher than that for gypsum No. 2 .

TABLE 2.-Grit content of fillers

\begin{tabular}{|c|c|c|c|}
\hline Kind of filler & Grit & Kind of filler & Grit \\
\hline $\begin{array}{l}\text { Asbestine } \\
\text { Talc } \\
\text { Clay No. } 1.200 \\
\text { Clay No. 2 }\end{array}$ & $\begin{array}{r}\text { Per cent } \\
10.190 \\
1.148 \\
.085 \\
.810\end{array}$ & $\begin{array}{l}\text { Clay No. } 3 \\
\text { Crown filler } \\
\text { Gypsum No. } 1 .\end{array}$ & $\begin{array}{r}\text { Per cent } \\
0.033 \\
.002 \\
2.893 \\
.008\end{array}$ \\
\hline
\end{tabular}

1 Not all grit, part fiber.

2 Mostly coarse particles of gypsum. (See text.)

(d) Color Mensurements.-The color, or degree of whiteness, of fillers is important in their selection, especially for use in highgrade papers. The usual method of comparing materials for color is to place them side by side and to grade them by the eye, but by this method it is impossible to show the variations quantitatively. Therefore, the color characteristics of the fillers in this investigation and of the papers containing them were determined by measurements made with a Pfund colorimeter, ${ }^{4}$ modified as found necessary

"Pfund, A. H., "A new colorimeter for white pigments and some results obtained by its use," Amer. Soc. for Test. Materials, June, 1920; also, B. S. Tech. Paper No. 244, A Measure of the Color Characteristics of White Papers, by R. E. Lofton. 
for materials of this nature. This instrument by means of multiple reflections enables measurements of very slight variations in color to be accurately made and numerical values assigned. The measurements on fillers were made on the dry material, since the color of

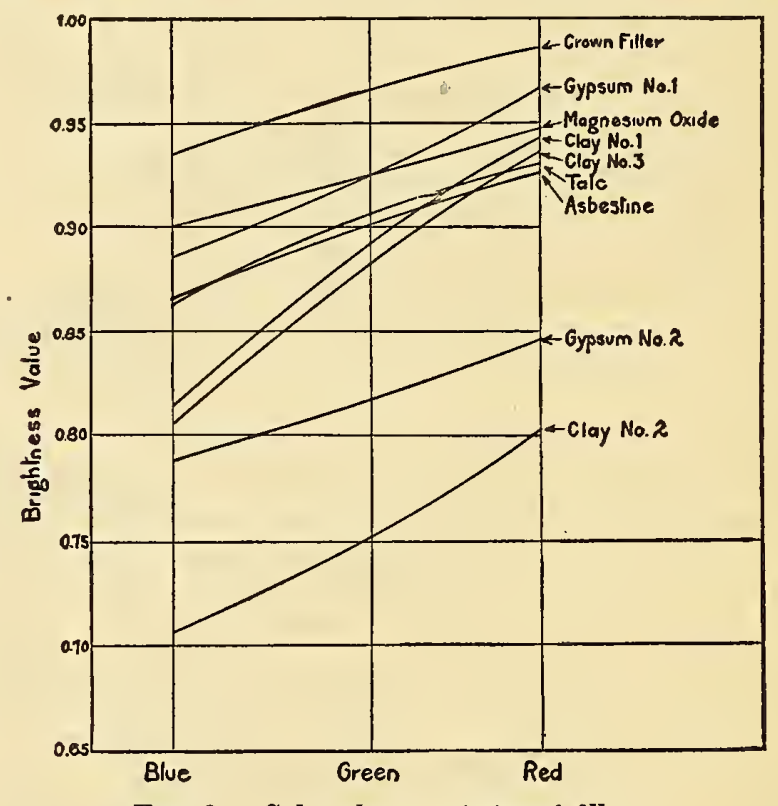

FIG. 2.-Color characteristics of fillers

filler when wet is usually different from the color when dry. A sample of chemically pure magnesium oxide was included with the fillers for comparison. The measurements obtained are given in Table 3 and shown graphically in Figure 2.

TABLE 3.-Color measurements of fillers 1

\begin{tabular}{|c|c|c|c|c|c|c|c|}
\hline \multirow{2}{*}{ Sample } & \multicolumn{3}{|c|}{ Brightness value } & \multirow{2}{*}{$\begin{array}{c}\text { Total } \\
\text { bright- } \\
\text { ness }\end{array}$} & \multicolumn{3}{|c|}{ Brightness } \\
\hline & Blue & Green & Red & & Blue & Green & Red \\
\hline $\begin{array}{l}\text { Magnesium oxide }{ }^{2} \\
\text { Asbestine._. } \\
\text { Talc } \\
\text { Clay No. 1. } \\
\text { Clay No. } 2\end{array}$ & $\begin{array}{l}0.900 \\
.862 \\
.861 \\
.813 \\
.706\end{array}$ & $\begin{array}{r}0.924 \\
.901 \\
.908 \\
.890 \\
.750\end{array}$ & $\begin{array}{r}0.946 \\
.924 \\
.927 \\
.941 \\
.801\end{array}$ & $\begin{array}{l}2.770 \\
2.687 \\
2.696 \\
2.644 \\
2.257\end{array}$ & \begin{tabular}{|c} 
Per cent \\
32.5 \\
32.1 \\
31.9 \\
30.8 \\
31.3
\end{tabular} & $\left\{\begin{array}{c}\text { Per cent } \\
33.3 \\
33.5 \\
33.7 \\
33.6 \\
33.2\end{array}\right.$ & $\begin{array}{r}\text { Per cent } \\
34.2 \\
34.4 \\
34.4 \\
35.6 \\
35.5\end{array}$ \\
\hline $\begin{array}{l}\text { Clay No. }{ }^{3} \\
\text { Crown filler } \\
\text { Gypsum No. 1. } \\
\text { Gypsum No. 2-- }\end{array}$ & $\begin{array}{l}.804 \\
.934 \\
.883 \\
.784\end{array}$ & $\begin{array}{l}.880 \\
.966 \\
.923 \\
.818\end{array}$ & $\begin{array}{l}.934 \\
.986 \\
.966 \\
.844\end{array}$ & $\begin{array}{l}2.618 \\
2.886 \\
2.772 \\
2.446\end{array}$ & $\begin{array}{l}30.7 \\
32.3 \\
31.8 \\
32.1\end{array}$ & $\begin{array}{l}33.6 \\
33.4 \\
33.3 \\
33.4\end{array}$ & $\begin{array}{l}35.7 \\
34.3 \\
34.9 \\
34.5\end{array}$ \\
\hline
\end{tabular}

1 Measurements made by R. E. Lofton, Bureau of Standards.

2 Magnesium oxide was included for comparison.

The color characteristics were determined in terms of the relative brightness of the three primary components-blue, green, and red. If the sample being tested were truly color neutral, "white" or gray, 
the brightness values for these three colors would be the same (that is, the samples would reflect nonselectively) and the color curve would be a straight, horizontal line. If the sample shows a slight hue (reflects selectively), the brightness values differ for the component colors. All "whites" seem to depart noticeably from true white. Figure 2 shows all the filler samples to be deficient in blue; that is, yellowish.

The curves of Figure 3 show more readily the color comparison of the fillers. The reading for blue was taken as the zero in each case.

The curve of color characteristics for a true white or a true gray would be a horizontal straight line, nonselective reflection, but the curve for white would be higher on the vertical scale; that is, white

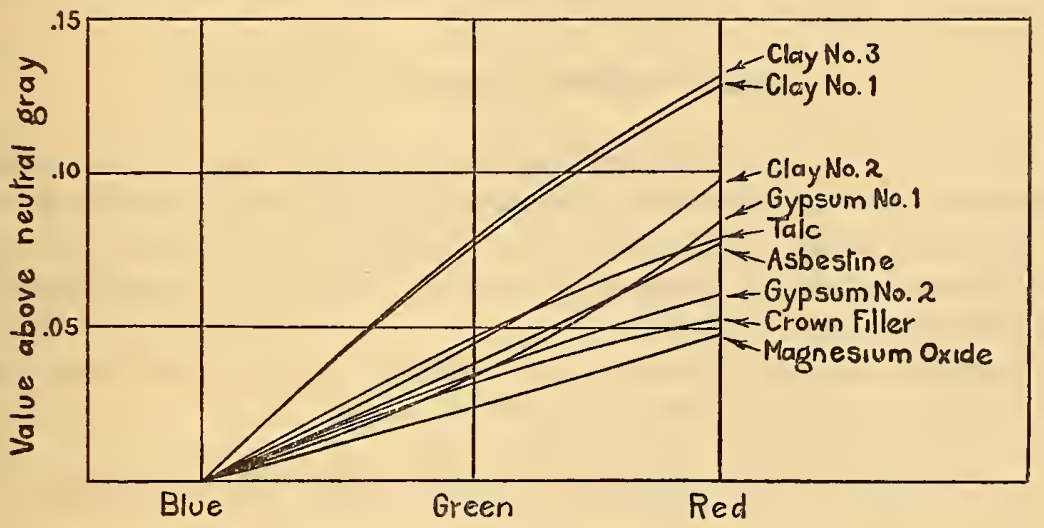

FIG. 3.-Color comparison of fillers

would be higher in brightness. The position of the curves in Figure 2 shows the relative brightness of the fillers. (The brightness differences are very nearly in the same proportion as the values for green shown in the curves.) These curves show gypsum No. 2 and clay No. 2 to be very low in brightness, "dead," although their color was fairly good.

\section{PAPER-MAKING EQUIPMENT USED}

The paper section of the Bureau of Standards is equipped for making paper in a semicommercial way and under practical mill conditions. The experimental paper-making equipment employed for the work on fillers consisted of a 50-pound wood tub beater with manganese-bronze bars and plate; a small Jordan with iron bars; a 4-plate screen; and a 29-inch Fourdrinier machine with wire 33 feet long and having two presses, nine 15-inch dryers, a small machine stack of seven rolls, and a reel. ${ }^{5}$ For part of the work a supercalendar was also used.

- Photographs of the above equipment are shown and the paper-making process described in B. S. Tech. Paper No. 262, pp. 340-341.

$61643^{\circ}-25-2$ 


\section{DESCRIPTION OF METHODS USED}

\section{ADDING FILLER}

The clay filler was made into a slip and added to the beater when furnishing; the other fillers were added dry with the furnish. Clays, being rarely free from foreign ingredients, are in commercial practice mixed with water and screened to remove dirt and impurities.

Various methods of preparing and adding the clay slip were tried in preliminary runs, ${ }^{6}$ but the method that proved most satisfactory, and therefore adopted, was adding the slip to the beater when furnishing, following later with the size, and adding the alum when the beating was near completion. (The size and alum were added similarly for the other fillers.)

\section{MACHINE OBSERVATIONS AND SAMPLING}

Since the methods employed in handling the machine and making observations were essentially the same as those previously described, ${ }^{6}$ it is unnecessary to repeat here the general procedure followed. Reference should be made to the earlier report for this information and for method of sampling.

Samples for filler retention data were taken at the stuff box, head box, after couch roll, and at the reel.

\section{DETERMINING PERCENTAGE OF ASH DUE TO FILLER}

The percentage of filler in the paper was determined as in the previous investigation. ${ }^{6}$ The steps involved reduce to the following formula:

in which

$$
\text { Per cent of filler in paper }=\frac{A-B}{1-C}
$$

$A=$ per cent of ash in bone-dry paper with filler,

$B=$ per cent of ash in bone-dry paper without filler,

$C=$ loss in weight of filler on ignition, expressed as fractional part of total weight.

\section{DETERMINING RETENTION}

The percentage of retention is considered as that proportion of the filler added to the beater furnish which appears in the finished paper. The different methods used in different laboratories for computing retention account in some degree for the varying results obtained and reported. In this investigation, for all fillers except 
crown filler and the gypsums, retention was determined by the formula ${ }^{7}$

in which

$$
\text { Retention }=\frac{0.94 B(100-C-A)}{A(100-C-B)}
$$

$A=$ per cent of ash in bone-dry stock going to machine,

$B=$ per cent of ash in bone-dry paper at reel,

$C=$ per cent of bone-dry filler lost on ignition.

The high degree of solubility of crown filler and the gypsums prevented the use of the formula for these fillers. For these, retention was computed by determining the percentage of filler in the paper, taking this per cent of the weight of paper made, and dividing the product by the weight of filler added to the furnish. Determinations made previously on numerous machine runs using clay as filler established the agreement of results obtained by this method with those determined by the formula, but the formula being more easily applied was used herein when applicable.

The formula should be used with discretion. Before being adopted for general use in a mill any retention formula should be tested to determine whether it is suited to the particular conditions with which that mill has to deal. Many factors other than filler influence retention, but it is impossible to estimate their effects except in a general way. Some of the conditions which affect the retention of fillers are: The kind of stock used; the extent of its beating (hydration); consistency of pulp and the amount of filler added; weight of paper made and speed of machine; the pull on the suction boxes, or any mechanical attachment to the machine which quickly removes water from the pulp; chemicals used, such as starch, sodium silicate, or viscose materials; and use of save-alls.

In the work of this investigation the beating, jordaning, and machine runs were controlled very carefully, the only changes made being the kind and percentage of filler added.

\section{TABULATION AND DISCUSSION OF TEST RESULTS}

Paper-machine runs were made on stock both with and without filler. The kind and percentage of filler added was varied, the amounts being 10 and 20 per cent, by weight, of the beater furnish. The data given in the following tables are in each case the average of two or more runs.

7 The authors are indebted to Edwin Sutermeister, of the S. D. Warren Co., Cumberland Mills, Me., for this formula, which is the one used in all the retention determinations in the earlier investigation on clays (B. S. Tech. Paper No. 262, p. 344). 


\section{SOLID MATERIAL IN PAPER AND MACHINE WATER SAMPLES}

Uniformity in the test procedure of the various machine runs is shown by the paper samples of Table 4. The concentration of stock at a given machine position differed little with kind of filler used. The machine waters, however, vary considerably. Relatively small amounts of solid material were removed by filtering the waters when crown filler and gypsum were employed but very much larger amounts remained in the filtrate. Crown filler and gypsum have, therefore, a high degree of solubility. The solid content of the filtrate when using the other fillers was practically all alum and size.

TABLE 4.-Solid material in samples

TESTS WITH 10 PER CENT FILLER IN FURNISH

\begin{tabular}{|c|c|c|c|c|c|c|c|c|c|c|}
\hline \multirow[b]{2}{*}{ Kind of filler } & \multicolumn{5}{|c|}{ In paper stock } & \multicolumn{3}{|c|}{ In water samples } & \multirow{2}{*}{\multicolumn{2}{|c|}{$\begin{array}{l}\text { In white water } \\
\text { No. } 1 \text { filtrate }\end{array}$}} \\
\hline & P P & Stuff & Head & After & Pol & White & W & Suc- & & \\
\hline $\begin{array}{l}\text { Stock without filler. } \\
\text { Asbestine } \\
\text { Talc } \\
\text { Clay No.1 } \\
\text { Clay No. } 2\end{array}$ & $\begin{array}{c}\text { Per } \\
\text { cent } \\
4.15 \\
4.55 \\
4.62 \\
4.86 \\
4.76\end{array}$ & $\begin{array}{c}\text { Per } \\
\text { cent } \\
2.65 \\
3.00 \\
3.00 \\
2.92 \\
3.12\end{array}$ & $\begin{array}{c}\text { Per } \\
\text { cent } \\
0.536 \\
.530 \\
.581 \\
.656 \\
.658\end{array}$ & $\begin{array}{l}\text { Per } \\
\text { cent } \\
22.00 \\
22.79 \\
22.70 \\
22.49 \\
23.52\end{array}$ & $\begin{array}{c}\text { Per } \\
\text { cent } \\
95.80 \\
96.43 \\
96.25 \\
96.96 \\
96.71\end{array}$ & $\begin{array}{c}\text { Lbs.per } \\
1,000 \\
\text { gals. } \\
1.46 \\
4.15 \\
4.91 \\
5.97 \\
5.04\end{array}$ & $\begin{array}{c}\text { Lbs.per } \\
1,000 \\
\text { gals. } \\
1.74 \\
3.47 \\
3.58 \\
4.78 \\
4.04\end{array}$ & $\begin{array}{c}\text { Lbs. per } \\
\text { 1,000 } \\
\text { gals. } \\
1.66 \\
6.04 \\
6.15 \\
7.93 \\
7.15\end{array}$ & $\begin{array}{c}\text { Parts } \\
\text { per } \\
\text { million } \\
351.4 \\
344.2 \\
350.2 \\
348.8 \\
357.9\end{array}$ & $\begin{array}{c}\text { Grains } \\
\text { per } \\
\text { gallon } \\
20.5 \\
20 . \\
20.4 \\
20.3 \\
20.8\end{array}$ \\
\hline $\begin{array}{l}\text { Clay No. } 3 \\
\text { Crown filler } \\
\text { Gypsum No.1 } \\
\text { Gypsum No. } 2 \\
\end{array}$ & $\begin{array}{l}4.71 \\
4.66 \\
4.45 \\
\text { 4. } 52\end{array}$ & $\begin{array}{l}3.04 \\
2.85 \\
2.87 \\
2.79\end{array}$ & $\begin{array}{r}.636 \\
.581 \\
.544 \\
.535\end{array}$ & $\begin{array}{l}23.57 \\
22.35 \\
23.13 \\
22.85\end{array}$ & $\begin{array}{l}96.76 \\
95.86 \\
95.95 \\
96.14\end{array}$ & $\begin{array}{l}5.16 \\
2.06 \\
1.74 \\
1.87\end{array}$ & $\begin{array}{l}3.76 \\
1.55 \\
1.62 \\
1.70\end{array}$ & $\begin{array}{l}7.71 \\
2.61 \\
2.15 \\
1.68\end{array}$ & $\begin{array}{r}355.8 \\
1,925.2 \\
1,541.1 \\
1,804.5\end{array}$ & $\begin{array}{r}20.7 \\
112.1 \\
89.8 \\
105.3\end{array}$ \\
\hline
\end{tabular}

TESTS WITH 20 PER CENT FILLER IN FURNISH

\begin{tabular}{|c|c|c|c|c|c|c|c|c|c|c|}
\hline $\begin{array}{l}\text { Asbestine } \\
\text { Talc } \\
\text { Clay No. 1 } \\
\text { Clay No. } 2\end{array}$ & $\begin{array}{l}5.25 \\
5.25 \\
5.34 \\
5.30\end{array}$ & $\begin{array}{l}\text { 3. } 37 \\
\text { 3. } 37 \\
\text { 3. } 45 \\
\text { 3. } 33\end{array}$ & $\begin{array}{r}0.648 \\
.692 \\
.720 \\
.701\end{array}$ & $\begin{array}{l}23.16 \\
23.16 \\
23.65 \\
24.33\end{array}$ & $\begin{array}{l}97.01 \\
96.26 \\
96.82 \\
96.93\end{array}$ & $\begin{array}{r}7.27 \\
7.27 \\
10.52 \\
9.47\end{array}$ & $\begin{array}{l}6.94 \\
6.72 \\
8.15 \\
6.99\end{array}$ & $\begin{array}{r}9.82 \\
9.96 \\
15.80 \\
13.75\end{array}$ & $\begin{array}{l}347.9 \\
424.7 \\
341.4 \\
415.1\end{array}$ & $\begin{array}{l}20.2 \\
24.7 \\
19.9 \\
24.2\end{array}$ \\
\hline $\begin{array}{l}\text { Clay No. } 3 \\
\text { Crown filler. } \\
\text { Gypsum No.1 } \\
\text { Gypsum No. } 2 .\end{array}$ & $\begin{array}{l}5.27 \\
5.07 \\
5.07 \\
5.17\end{array}$ & $\begin{array}{l}\text { 3. } 42 \\
\text { 3. } 21 \\
\text { 3. } 13 \\
\text { 3. } 24\end{array}$ & $\begin{array}{l}.753 \\
.635 \\
.681 \\
.648\end{array}$ & $\begin{array}{l}24.27 \\
22.54 \\
24.31 \\
24.48\end{array}$ & $\begin{array}{l}97.07 \\
94.91 \\
96.71 \\
95.73\end{array}$ & $\begin{array}{l}9.30 \\
3.14 \\
4.85 \\
4.25\end{array}$ & $\begin{array}{l}7.10 \\
4.61 \\
6.07 \\
6.19\end{array}$ & $\begin{array}{r}12.62 \\
2.32 \\
4.08 \\
2.17\end{array}$ & $\begin{array}{r}378 \cdot 6 \\
2,308.7 \\
2,036.2 \\
2,491.2\end{array}$ & $\begin{array}{r}22.0 \\
134.6 \\
118.6 \\
145.1\end{array}$ \\
\hline
\end{tabular}

\section{FILLER CONTENT OF SAMPLES}

In Table 5 are given the amounts of filler in the suspended material of the various samples and the retention value for each. In every case the amount of filler in the paper samples is less for crown filler and gypsums (the soluble materials). The retention values for these substances are, therefore, low.

The stock in the machine waters, as shown in the last three columns of Table 5, contained very small amounts of crown filler or gypsum when 10 per cent was added to the beater furnish, but the increase in amount was much greater proportionally when 20 per cent was added. The water had then become more nearly saturated with the 
soluble filler. If still larger amounts of filler were added, or if machine water were used instead of fresh water in furnishing the beater, the retention in the finished paper would differ little with the kind of filler added.

The difference noted in the filler content of the machine water for the two gypsum samples in the 10 per cent runs was doubtless due to the difference in fineness of the particles. (See Section III, $2(a)$.)

TABLE 5.-Filler in suspended material of samples

TESTS WITH 10 PER CENT FILLER IN FURNISH

\begin{tabular}{|c|c|c|c|c|c|c|c|c|c|}
\hline \multirow[b]{2}{*}{ Kind of filler } & \multirow[b]{2}{*}{$\begin{array}{c}\text { Reten- } \\
\text { tion }\end{array}$} & \multicolumn{5}{|c|}{ In paper stock } & \multicolumn{3}{|c|}{ In water samples } \\
\hline & & Beater & $\begin{array}{l}\text { Stuff } \\
\text { box }\end{array}$ & $\begin{array}{l}\text { Head } \\
\text { box }\end{array}$ & $\begin{array}{l}\text { After } \\
\text { couch } \\
\text { roll }\end{array}$ & Reel & $\begin{array}{l}\text { White } \\
\text { water } \\
\text { No. } 1\end{array}$ & $\begin{array}{l}\text { Wire } \\
\text { water }\end{array}$ & $\begin{array}{c}\text { Suction } \\
\text { water }\end{array}$ \\
\hline $\begin{array}{l}\text { Asbestine..... } \\
\text { Tale.-. } \\
\text { Clay No.1... } \\
\text { Clay No. 2... }\end{array}$ & $\begin{array}{r}0.736 \\
.759 \\
.694 \\
.728\end{array}$ & $\begin{array}{r}\text { Per ct. } \\
9.78 \\
9.81 \\
9.67 \\
9.80\end{array}$ & $\begin{array}{r}\text { Per ct. } \\
9.66 \\
10.09 \\
9.67 \\
9.71\end{array}$ & $\begin{array}{r}\text { Per ct. } \\
13.58 \\
13.77 \\
12.65 \\
12.70\end{array}$ & $\begin{array}{r}\text { Per ct, } \\
7.50 \\
8.30 \\
7.32 \\
7.73\end{array}$ & $\begin{array}{r}\text { Per ct. } \\
7.44 \\
8.17 \\
7.14 \\
7.54\end{array}$ & $\begin{array}{r}P e r c t . \\
65.07 \\
53.45 \\
57.45 \\
62.65\end{array}$ & $\begin{array}{r}\text { Per ct. } \\
65.57 \\
65.00 \\
56.70 \\
59.25\end{array}$ & $\begin{array}{r}\text { Pet ct. } \\
65.87 \\
55.60 \\
61.55 \\
64.50\end{array}$ \\
\hline $\begin{array}{l}\text { Clay No. } 3 \\
\text { Crown filler } \\
\text { Gypsum No.1 } \\
\text { Gypsum No.2 }\end{array}$ & $\begin{array}{l}.744 \\
.085 \\
.235 \\
.085\end{array}$ & $\begin{array}{r}10.00 \\
6.20 \\
6.48 \\
5.85\end{array}$ & $\begin{array}{l}9.88 \\
3.22 \\
4.05 \\
3.05\end{array}$ & $\begin{array}{r}12.95 \\
2.03 \\
6.32 \\
2.16\end{array}$ & $\begin{array}{l}8.06 \\
1.22 \\
2.79 \\
1.39\end{array}$ & $\begin{array}{r}7.83 \\
.98 \\
2.65 \\
.98\end{array}$ & $\begin{array}{r}61.80 \\
.92 \\
26.17 \\
3.79\end{array}$ & $\begin{array}{r}57.95 \\
2.16 \\
37.25 \\
6.60\end{array}$ & $\begin{array}{r}66.10 \\
1.10 \\
20.10 \\
4.22\end{array}$ \\
\hline
\end{tabular}

TISTS WITH 20 PER CENT FILLER IN FURNISH

\begin{tabular}{|c|c|c|c|c|c|c|c|c|c|}
\hline $\begin{array}{l}\text { Asbestine } \\
\text { Talc. } \\
\text { Clay No. } 1 . \\
\text { Clay No. } 2\end{array}$ & $\begin{array}{r}0.718 \\
.730 \\
.665 \\
.666\end{array}$ & $\begin{array}{l}19.47 \\
20.11 \\
19.30 \\
19.75\end{array}$ & $\begin{array}{l}19.50 \\
20.02 \\
19.35 \\
19.87\end{array}$ & $\begin{array}{l}24.52 \\
24.10 \\
24.20 \\
24.50\end{array}$ & $\begin{array}{l}15.72 \\
16.14 \\
14.63 \\
14.71\end{array}$ & $\begin{array}{l}15.47 \\
16.15 \\
14.37 \\
14.42\end{array}$ & $\begin{array}{l}69.25 \\
70.15 \\
72.90 \\
70.55\end{array}$ & $\begin{array}{l}68.05 \\
69.25 \\
68.70 \\
72.10\end{array}$ & $\begin{array}{l}72.10 \\
70.15 \\
73.20 \\
74.20\end{array}$ \\
\hline $\begin{array}{l}\text { Clay No, } 3 \\
\text { Crown filler } \\
\text { Gypsum No.1. } \\
\text { Gypsum No. 2 }\end{array}$ & $\begin{array}{l}.731 \\
.403 \\
.365 \\
.376\end{array}$ & $\begin{array}{l}19.82 \\
16.47 \\
16.65 \\
15.45\end{array}$ & $\begin{array}{l}19.78 \\
13.84 \\
13.85 \\
13.95\end{array}$ & $\begin{array}{l}24.10 \\
16.41 \\
18.12 \\
18.30\end{array}$ & $\begin{array}{r}16.02 \\
10.25 \\
8.77 \\
9.21\end{array}$ & $\begin{array}{r}15.95 \\
9.57 \\
8.62 \\
8.66\end{array}$ & $\begin{array}{l}74.80 \\
39.50 \\
68.75 \\
59.40\end{array}$ & $\begin{array}{l}71.40 \\
67.56 \\
68.80 \\
69.90\end{array}$ & $\begin{array}{r}77.00 \\
.20 \\
36.40 \\
22.23\end{array}$ \\
\hline
\end{tabular}

\section{MEASUREMENTS ON FINISHED PAPER}

The data obtained on the finished paper are given in Table 6 . Weights are included in terms of a ream containing 500 sheets, 25 by 40 inches and 25 by 38 inches, respectively.

The measurements show, in general, greater strength and better sizing for the paper containing the soluble fillers than for that containing asbestine, talc, or clay. The values for the former differ less from the corresponding values for paper without filler. The 20 per cent runs for crown filler and the gypsums and the 10 per cent runs for asbestine, talc, and clay permit comparison of paper containing more nearly equal amounts of filler. (See " $\Lambda$ sh" values.) Such comparison indicates that the difference in strength and sizing noted above is attributable to difference in amount, not kind, of filler in the paper. 
All fillers have an effect on the sizing qualities of paper, and their influence becomes more noticeable as the amount added increases. Sizing is a surface phenomenon. When paper is sized, the surface of the fibers and filler composing the sheet becomes coated with the sizing agent. With the addition of filler the increase in surface area is much greater than the increase in weight. Therefore, since the amount of size added is determined on a weight basis, paper without filler has better sizing quality. Freedom from chemical reaction with the sizing agent is a requirement of good fillers, as such property reduces the decrease in sizing quality that occurs when filler is added. As shown in Table 6, sizing was not affected by any of the fillers of this investigation.

Finish is improved and opacity is increased when filler is added. Finish as reported in Table 6 did not vary with kind of filler, but opacity is less for the soluble materials (smaller amounts being retained in the finished paper).

The color observations show the dominant hue to be practically the same for all papers but the brightness to be relatively low for clay No. 2 and gypsum No.2. The comparatively small amounts of filler in the finished papers are, in general, not sufficient to produce variations attributable to the color characteristics of the filler material. Any outstanding differences in the color of the fillers are, however, also noted in the papers. The relatively low brightness for clay No. 2 and gypsum No. 2 (p. 738) was observed also for the papers containing these materials. 


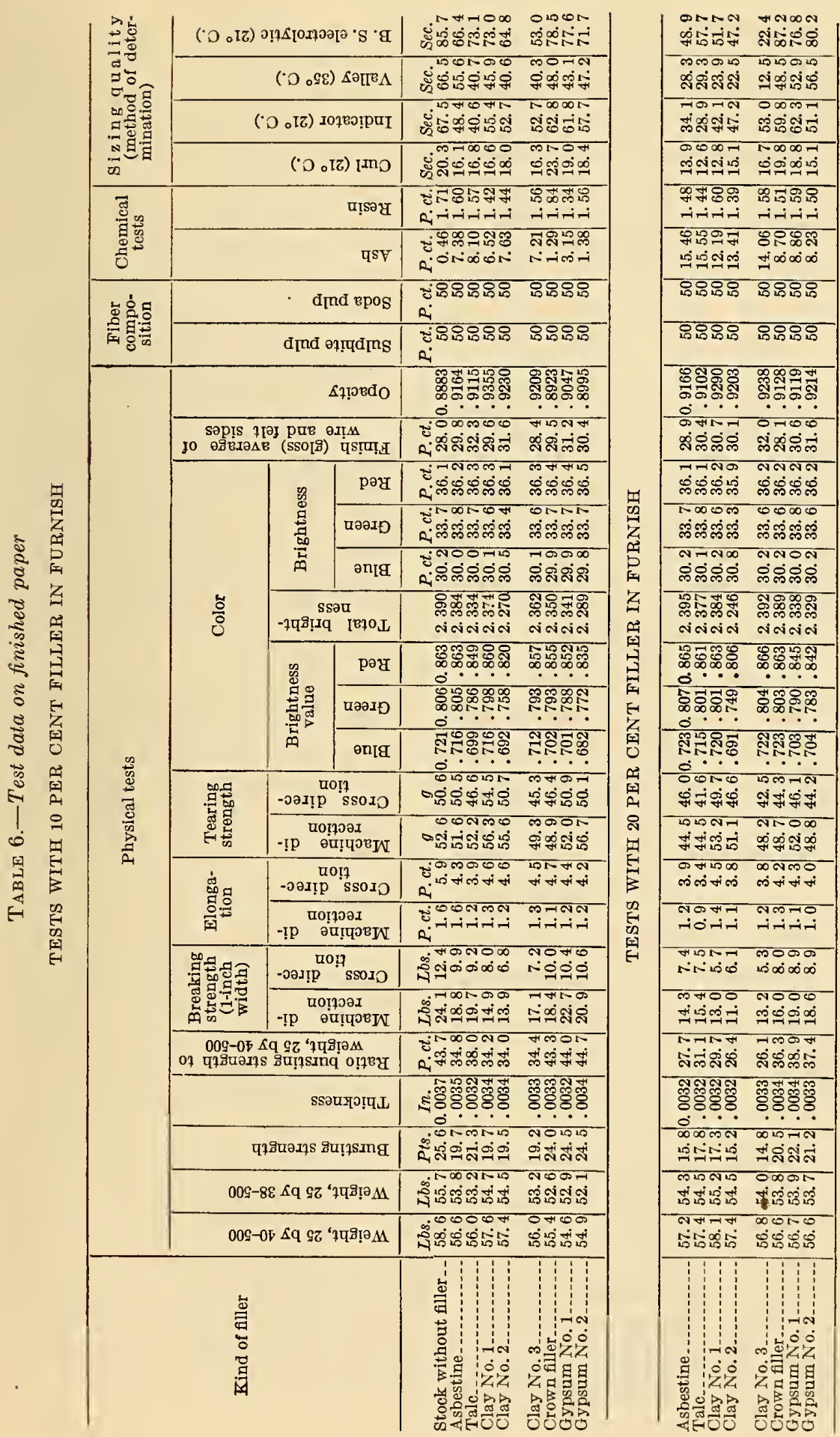


Sheets from the paper made were supercalendered and subsequently measured for finish, opacity, and thickness. The values obtained are compared in Table 7 with similar measurements made after leaving the paper-making machine. The reported values are each for one sample only, but are included as being of general interest.

TABLE 7.-Effect of supercalendering on paper

TESTS WITH 10 PER CENT FILLER IN FURNISH

\begin{tabular}{|c|c|c|c|c|c|c|c|c|c|}
\hline \multirow[b]{2}{*}{ Kind of filler } & \multicolumn{3}{|c|}{ Finish } & \multicolumn{3}{|c|}{ Opacity } & \multicolumn{3}{|c|}{ Thickness } \\
\hline & $\begin{array}{l}\text { Before } \\
\text { super- } \\
\text { calen- } \\
\text { dering }\end{array}$ & $\begin{array}{l}\text { After } \\
\text { super- } \\
\text { calen- } \\
\text { dering }\end{array}$ & $\begin{array}{c}\text { In- } \\
\text { crease }\end{array}$ & $\begin{array}{l}\text { Before } \\
\text { super- } \\
\text { calen- } \\
\text { dering }\end{array}$ & $\begin{array}{l}\text { After } \\
\text { super- } \\
\text { calen- } \\
\text { dering }\end{array}$ & $\begin{array}{c}\text { De- } \\
\text { crease }\end{array}$ & $\begin{array}{l}\text { Before } \\
\text { super- } \\
\text { calen- } \\
\text { dering }\end{array}$ & $\begin{array}{l}\text { After } \\
\text { super- } \\
\text { calen- } \\
\text { dering }\end{array}$ & $\begin{array}{c}\text { De- } \\
\text { crease }\end{array}$ \\
\hline $\begin{array}{l}\text { Stock without filler. } \\
\text { Asbestine } \\
\text { Talc. } \\
\text { Clay No. } 1 \\
\text { Clay No. } 2 .\end{array}$ & $\begin{array}{r}\text { Per cent } \\
28.0 \\
28.7 \\
33.0 \\
29.2 \\
31.9\end{array}$ & \begin{tabular}{|} 
Per cent \\
51.5 \\
55.5 \\
55.5 \\
58.5 \\
54.5
\end{tabular} & \begin{tabular}{|r|} 
Per cent \\
84.0 \\
91.5 \\
68.0 \\
100.0 \\
71.0
\end{tabular} & $\begin{array}{r}0.8746 \\
.9148 \\
.9120 \\
.9358 \\
.9201\end{array}$ & $\begin{array}{r}0.8872 \\
.8828 \\
.8828 \\
.8958 \\
.8947\end{array}$ & $\begin{array}{r}-1.44 \\
3.50 \\
3.20 \\
4.27 \\
2.76\end{array}$ & $\begin{array}{l}\text { Inch } \\
0.0037 \\
.0035 \\
.0034 \\
.0035 \\
.0034\end{array}$ & $\begin{array}{l}\text { Inch } \\
0.0030 \\
.0028 \\
.0029 \\
.0029 \\
.0030\end{array}$ & $\begin{array}{r}\text { Per cent } \\
18.9 \\
20.0 \\
14.7 \\
17.1 \\
11.8\end{array}$ \\
\hline $\begin{array}{l}\text { Clay No. } 3 \\
\text { Crown filler. } \\
\text { Gypsum No. } 1 \\
\text { Gypsum No. } 2\end{array}$ & $\begin{array}{l}30.0 \\
28.6 \\
30.3 \\
28.2\end{array}$ & $\begin{array}{l}56.5 \\
55.8 \\
53.0 \\
55.0\end{array}$ & $\begin{array}{l}88.0 \\
95.0 \\
75.0 \\
95.0\end{array}$ & $\begin{array}{l}.9244 \\
.8895 \\
.9116 \\
.8916\end{array}$ & $\begin{array}{l}.8913 \\
.8921 \\
.8700 \\
.8942\end{array}$ & $\begin{array}{r}3.50 \\
-.18 \\
4.56 \\
-.29\end{array}$ & $\begin{array}{l}.0033 \\
.0031 \\
.0032 \\
.0033\end{array}$ & $\begin{array}{l}.0025 \\
.0031 \\
.0029 \\
.0030\end{array}$ & $\begin{array}{r}24.2 \\
.0 \\
9.4 \\
9.1\end{array}$ \\
\hline
\end{tabular}

TESTS WITH 20 PER CENT FILLER IN FURNISH

\begin{tabular}{|c|c|c|c|c|c|c|c|c|c|}
\hline $\begin{array}{l}\text { Asbestine } \\
\text { Talc. } \\
\text { Clay No.1 } 1 .\end{array}$ & $\begin{array}{l}27.1 \\
31.5 \\
29.7 \\
30.0\end{array}$ & $\begin{array}{l}59.4 \\
58.0 \\
56.5 \\
59.0\end{array}$ & $\begin{array}{r}119.0 \\
84.0 \\
90.0 \\
96.5\end{array}$ & $\begin{array}{r}0.9180 \\
.9031 \\
.9374 \\
.9222\end{array}$ & $\begin{array}{r}0.8854 \\
.8942 \\
.9190 \\
.9239\end{array}$ & $\begin{array}{r}3.55 \\
.98 \\
1.96 \\
-.18\end{array}$ & $\begin{array}{r}0.0031 \\
.0032 \\
.0034 \\
.0031\end{array}$ & $\begin{array}{r}0.0029 \\
.0027 \\
.0028 \\
.0026\end{array}$ & $\begin{array}{r}6.4 \\
15.6 \\
17.6 \\
16.1\end{array}$ \\
\hline $\begin{array}{l}\text { Clay No. 3 } \\
\text { Crown filler } \\
\text { Gypsum No. } 1 . \\
\text { Gypsum No. 2 }\end{array}$ & $\begin{array}{l}32.0 \\
27.0 \\
30.5 \\
31.9\end{array}$ & $\begin{array}{l}59.0 \\
53.0 \\
54.0 \\
55.5\end{array}$ & $\begin{array}{l}84.5 \\
96.5 \\
77.0 \\
74.0\end{array}$ & $\begin{array}{l}.9298 \\
.9148 \\
.9212 \\
.9174\end{array}$ & $\begin{array}{l}.8942 \\
.8833 \\
.8761 \\
.9244\end{array}$ & $\begin{array}{r}3.83 \\
3.45 \\
4.90 \\
-.76\end{array}$ & $\begin{array}{l}.0032 \\
.0032 \\
.0034 \\
.0033\end{array}$ & $\begin{array}{l}.0025 \\
.0029 \\
.0028 \\
.0027\end{array}$ & $\begin{array}{r}21.8 \\
9.4 \\
17.6 \\
18.2\end{array}$ \\
\hline
\end{tabular}

\section{SUMMARY AND CONCLUSIONS}

The kind of filler material best suited for use in paper depends considerably on the use for which the paper is designed. Various fillers are employed for general use, however, but there is a lack of definite data as to their comparative paper-making value. To obtain such data the investigation herein reported was made.

The conclusions are based on results obtained on 8 commercial fillers-asbestine, talc, three clays, crown filler, and two gypsums. Papers were made from furnish containing 10 and 20 per cent of filler, respectively. The work was conducted under practical mill conditions and on a semicommercial scale. The study included amount of filler retained, quality of paper produced, and those properties of the filler (grit, etc.) that might affect the paper-making operations. From a comparison of all these data and considering the essential requirements of a good filler for paper, the following general conclusions are drawn: 
1. Relative cost can not be taken as a criterion of the general paper-making value of fillers. The cheapest clay was as good as the one costing twice as much, and crown filler was no better than gypsum.

2. Asbestine and talc have approximately the same paper-making properties and are in this respect comparable to the better clays. Crown filler and gypsum, being soluble in water, differ in amount of retention from the other fillers, all of which are practically insolublc.

3. Crown filler and gypsum have relatively low retentive qualities when the usual machine water system is employed and the fillers are added in the usual amounts.

4. The comparatively small amounts of filler in finished paper are not sufficient to produce variations attributable to the color characteristics of the fillers employed, unless pronounced differences in color are evident in the filling materials. Only fillers of good color were included in the investigation.

5. The sizing process and other paper-making operations were not adversely affected by any of the materials.

6. The differences in opacity, finish, strength, and degree of sizing were due chiefly to the differencc in retention of the fillers.

\section{BIBLIOGRAPHY}

The references given below were compiled by Clarence J. West, National Research Council, Washington, D. C., chairman of committee on bibliography, Technical Association of the Pulp and Paper Industry.

Alexander, J., Bentonite and its properties. Paper, 35, No. 3, p. 100, November $6,1924$.

Arnould, E., Use of mineral fillers in paper. Papier, 25, pp. 59-62; 1922.

Biedermannsdorf, H. P., New ideas on paper fillers. Paper, 33, No. 12, pp. 13-14, January 10, 1924.

Bouvier, F. M., Determining the quality of loading materials for paper. Mon. papeterie francaise, $\mathbf{5 3}$, p. $13 ; 1922$.

China clay as coater and filler. Paper, 29, No. 23, pp. 10-11, February 8, 1922.

Collins, H. F., China clay, its composition, preparation, and uses. J. Soc. Chem. Ind., 42, pp. 88-91, 114-117, 1923; Paper Maker, 65, pp. 331-332, March, 1923.

Deposition of fillers in paper. Papier-Ztg., 46, p. 4334, 1921; World's Paper Trade Rev., 77, p. 72; 1922.

Filling materials of the paper industry. Papierfabr., 20, pp. 1064-1067; 1922.

Ladoo, R. B., Bentonite, U. S. Bur. Mines, Repts. of investigations No. 2289; 1921. (5 pp.)

Lodge, W. C., Use of Canadian tale in paper making. Paper, 33, No. 15, pp. 22-25, January 31, 1924; Pulp and Paper Mag. of Can., 22, No. 4, pp. 102104, 114, January 24, 1924.

Milhan, E. G., Fillers. Paper Ind., 6, pp. 555 and 557, 1924; Paper 34, No. 9, pp. 372-373, June 19, 1924; Paper Mill, 48, No. 21, pp. 40-42, May 2t, 1924.

Paper fillers and loaders. Chem. Age (London), 11, suppl., pp. 1S-19, August $16,1924$. 
Postl, H., Chalk as filler. Wochbl. Papierfabr., 55, No. 45, pp. 2881-2882, November 15, 1924.

Postl, H., Paper fillers. Papierfabr., 21, pp. 541-544, 1923; Paper, 33, No. 12, pp. 13-14; 1924.

Reymond and Bouvier, Paper fillers. Papeterie, 45, pp. 681-684, 1923; Paper, 32, No. 22, pp. 5-8, September 19, 1923; Science et Industrie 7, No. 108, pp. 61-64, 1924.

Schneider, Carl C., Loading and filling substances and their retention properties, Paper, 31, No. 11, pp. 32-33, January 3, 1923; Paper Mill, 46, No. 45, pp. 18 and 46, November 18, 1924; Paper Ind., 4, No. 9, pp. 1259 and 1261, December, 1922.

Shaw, M. B., and Bicking, G. W., Comparison of American and foreign clays as paper fillers. U. S. Bureau of Standards Tech. Paper No. 262, 1924 (pp. 337-380). In part in Paper Trade Jour., 79, No. 18, pp. 119-122; 1924.

Shawcross, R., Talc in paper making. Paper Making, 61, No. 8, pp. 254-255; No. 9, pp. 269-270; No. 10, pp. 314-315; 1922.

Sieber, Rudolf, Leime und Füllen von Papierstoff, In Carl Hofmann's Pratisches Handbuch der Papierfabrikation, 3rd. ed., 3; 1923.

Spencer, G. K., Effect of artificially colored clay on fast-to-light paper. Am. Dyestuff Rep., 12, pp. 890-891; 1923.

Spencer, G. K., Value of domestic (U. S.) clays recognized. Paper, 35, No. 5, pp. 173-174, November 20, 1924.

Strachan, James, Standardization of china clay. Chem. Trade Jour., 70, pp. $669-671 ; 1922$.

Strachan, James, Natural history of china clay, with reference to its color and impurities. Proc. Tech. Sect., Paper maker's Assoc. Gt. Brit. and Ireland, 4, pt. 2, pp. 176-177; 1924.

Strupp, Ernst, and Rose, Paul, Chalk as a filler for paper. Papierfabr., 22, pp. 318-319; 1924.

Weigel, W. M., Size and character of grains of nonmetallic mineral fillers. U. S. Bur. Mines, Tech. Paper No. 296; 1924 (44 pp.).

Washington, June 16, 1925. 


\section{INDEX TO VOLUME 19}

\section{$\Delta$}

Air flow through engine radiators, a hot-wire anemometer for measuring

Airship ballasting, condensation of water from engine exhaust for

Aitchison, C. S., L. B. Tuckerman and, Design of specimens for short-time "fatigue" tests_.

Anderson, Robert J., and Everett G. Fahlman, Release of internal stress in brass tubing...

Anemometer, a hot-wire, for measuring air flow through engine radiators................

B

Bags, mail, comparative qualities of Pima and ordinary cotton used in

Ballasting, condensation of water from engine exhaust for airship.

Bending test, standard, for rope yarns......-

Bicking, George $W$., Merle B. Shaw and, A comparative study of paper fillers

Bowket, R. C., and M. N. V. Geib, Comparative durability of chrome and vegetable tanned sole leathers.

Boyden, Robert C., Charles W. Schoffstall and, Development of a standard bending test for rope yarn

Brass tubing, release of internal stress in

Broadcast reception, radio-frequency resistance and inductance of coils used in. .......

Broadcasting stations, study of conditions affecting the distance range of radiotele. phone.

Brick, fre-clay, testing of, with special reference to their use in coal-fired boiler settings.

Brick walls, sand-lime, compressive strength of

\section{O}

Carroll, L. B., Carl G. F. Zobel and, A hotwire anemometer for measuring air flow through engine radiators

Coment sacks, relative merits of cotton and jute.

Chrome and vegetable tanned sole leathers, comparative durability of

Cleaning, dry, reclamation of gasoline used

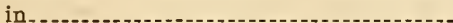

Coils, used in broadcast reception, radio-froquency resistanco and inductance of.....

Cold-rolling tcsts, comparative, of openhearth steel strip (deep-drawing stock) and electrolytic iron strip
Page

Concrete slabs, hollow tile and, reinforced in one direction.

Cotton, Pima and ordinary, used in mail

bags, comparative wearing qualities of....

Cotton and jute cement sacks, relative merits of

Cotton machinery, technology of

Curtis, H.L., and A. T. McPherson, Dielectric constant, power factor, and resistivity

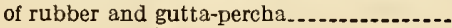

\section{D}

De Groot, H. B., August Hund and, Radiofrequency resistance and inductance of coils used in broadcast reception

Design of specimens for short-time "fatigue" tests.

E

723

Effect of twist on the physical properties of a number of $7 \mathrm{~s}$ yarn

Exhaust for airship ballasting condensation

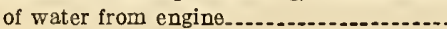

\section{F}

Fahlman, Everett G., Robert J. Anderson and, Release of internal stress in brass tubing...

"Fatiguc" tests, design of specimens for

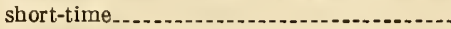

Fillers, a comparative study of paper.......

Fire-clay brick, tcsting of, with special reference to their use in coal-fired boiler settings.

France, R. D., John R. Freeman, jr., and, Comparative cold-rolling tests of openhearth steel strip (deep-drawing stock) and electrolytic-iron strip.

Freeman, jr., John R., and R. D. France, Comparative cold-rolling tests of openhearth steel strip (deep-drawing stock) and electrolytic-iron strip

French, $H$. J., and 0 . ?. Klopsch, Initial temperature and mass cffects in que nching...and W. A Tucker, Flow in a low-carbon steel at various temperatures...............

Fuel consumption, effect of tire resistance on

Gas and its uscfulnoss to the consumer, relation between heating valuo of .............

Gasoline, reclamation of, used in dry clean-

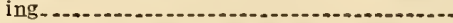

Geller, $R$. F., Testing of fire-clay brick with special reference to their use in coal-fired boiler settings
Page 465

73

515

183

669

651

47

537

235

47

733

97

297

297

$5 \mathrm{~S}$

619

213 
Gieb, M. N. V., R. C. Bowker and, Comparative durability of chrome and vegetable tanned sole leathers.

Gutta-percha, dielectric constant, power factor, and resistivity of rubber and.

\section{H}

Hall, E. L., J. L. Prcston and, A study of the seasonal variation of radio-frequency phase difference of laminated phenolic insulation materials

Heating value of gas and its usefulness to the consumer, relation between.

Hickson, E. F., P. H. Walker and, Use of United States Government specification paints and paint materials..

Holt, W $L$, and $P, L$ Wormeley, Effect of tire resistance on fuel consumption

$\longrightarrow$ and $P$. L. Wormeley, Wearing qualities of tire treads as influenced by reclaimed rubber.

Hot-wire anemometer for measuring air flow through engine radiators

Hubbard, C. C., Reclamation of gasoline used in dry cleaning.

Hund, August, and H. B. De Groot, Radiofrequency rcsistance and inductance of coils used in broadcasting reception

Inductance of coils used in broadcast reception, radio-frequency resistance and ........ Internal stress in brass tubing, release of..... Insulating materials, a study of the seasonal $\nabla$ ariation of radio-frequency phase difference of laminated phenolic insulating materials

Jansky, jr., C. M., A statistical study of conditions affecting the distance range of telephone broadcasting stations

Jute cement sacks, relative merits of cotton and

\section{K}

Klopsch, O. Z., H. J. French and, Initial tem. perature and mass effects in quenching.-$K 0 h r$, Robert $F$., Condensation of water from engine exhaust for airship ballasting ......-.

\section{L}

Leathers, sole, chrome and vegetable tanned, comparative durability of

Low-carbon steel, flow in at various temperatures

\section{M}

McGowan, F. R., Charles W. Schoffstall, and A. A. Mercier, Comparative wearing qualities, of Pima and ordinary cotton used in mail bags

-. Charles W Schoffstall and A. A Mercier, Effect of twist on the physical properties of a

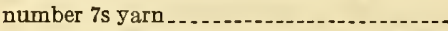
- F. W. Smithers, and Charles W. Schoffstall, Performance tests of a liquid laundry soap used with textile materials.
141 651
Mail bags, comparative qualities of Pima and ordinary cotton used in.................. Malleability and metallography of nickel.-.Mass effects in quenching, initial temperature and

Merica, P. D., and R. G. Waltenberg, Malleability and metallography of nickel......... Mercier, A. A., Technology of cotton machinery. Part I.-Calculations on pickers_ - F. R. McGowan, Charles W. Schoffstall and, Effect of twist on the physical properties of a number of 7s yarn.............. - F. R. McGowan, Charles W. Schoffstall and, Comparative wearing qualities of Pima and ordinary cotton used in mail

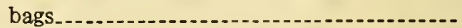

Morris, Robert $J$, Relative merits of cotion and jute cement sacks.

$\mathrm{N}$

McPherson, A. T., H. L. Curtis and, Di$N$

Nickel, malleability and metallography of... Notched bar tests, comparative slow bend and impact, on some metals.

$$
\mathbf{P}
$$

Paint materials, use of United States Government specification....................... Paints, use of United States Government specification.

Paper fillers, a comparative study of

Parsons, Douglas E., and Ambrose H. Stang, Tests of hollow tile and concrete slabs reinforced in one direction.-.... Performance tests of a liquid laundry soap used with textile materials.................... Petrenko, S. N., Comparative slow bend and impact notched bar tests on some metals.Pima and ordinary cotton used in mail bags, comparative wearing qualities of.......... Power factor of rubber and gutta-percha...Preston, J. L., and E. L. Hall, A study of the seasonal variation of radio-frequency phase difference of laminated phenolic insulating materials

\section{Q}

Quenching, initial temperature and mass effects in

\section{R}

Radiators, engine, a hot-wire anemometer for measuring air flow through...........

Radio-frequency phase difference of laminated phenolic insulating materials........

Radio-frequency resistance and inductance of coils used in broadcast reception........

Radio telephone broadcasting stations, study of conditions affecting the distance range of Reclaimed rubber, wearing qualities of tire treads as influenced by .................. Resistivity of rubber and gutta-percha......
669 183 73 
Rope yarns, a standard bending test for

Rubber and gutta-percha, dielectric constant, power factor, and resistivity of

Rubber, reclaimed, wearing qualities of tire treads as influenced by

\section{$\mathrm{S}$}

Sacks, cement, relative merits of cotton and jute.

Sand-lime brick walls, compressive strength of

Schoffstall, Charles W., and Robert $C$. Boyden, Development of a standard bending test for rope yarns.

- F. R. McGowan, F. W. Smither and Performance tests of a liquid laundry soap used with textile materials_...................

- F. R. McGowan, A. A. Mercier and Effect of twist on the physical properties of a number of $7 \mathrm{~s}$ yarn

- F. R. McGowan, A. A. Mercier and Comparative wearing qualities of Pima and ordinary cotton used in mail bags

Shaw, Merle B., and George W. Bicking, A comparative study of paper fillers.........

Slabs reinforced in one direction, test of hollow tile and concrete.

Slow bend and impact notched bar tests on some metals

Smither, F. W., F. R. McGowan, Charles W. Schoffstall and, Performance tests of a liquid laundry soap used with tcxtile materials... Soap, liquid laundry, tests of

Sole leathers, comparative durability of chrome and vegetable tanned.

Stang, Ambrose H., Douglas $E$. Parsons and, Tests of hollow tile and concrete slabs reinforced in one direction........................

Stang, A. H., H. L. Whittemore and, Compressive strength of sand-lime brick walls..

Stations, study of conditions affecting distance range of radio telephone broadcasting -

Steel, low-carbon, flow in at various temperatures

strip, open-hearth, comparative coldrolling tests.

Strengtl, compressive, of sand-lime brick

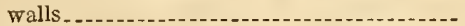
Stress, internal, relcase of, in brass tubing.

$$
\mathrm{T}
$$

Technology of cotton machinery

Tempcrature and mass effects in quenching.

Test, standard bending for rope yarns .......

Testing of fire-clay brick with special reference to their use in coal-fired boiler settings. age
Tests, comparative cold-rolling, of openhearth steel strip (deep-drawing stock) and electrolytic iron strip comparative slow bend and impact notched bar, on some metals........... design of specimens for short-time "fatigue"

of hollow tile and concrete slabs reinforced in one direction of liquid laundry soap

Tile, hollow, and concrete slabs reinforced in one direction.

Tire resistance on fuel consumption, effect of

Tire treads, wearing qualities of, as influenced by reclaimed rubber

Treads, tire, wearing qualities of, as influenced by reclaimed rubber

Tubing, brass, release of internal stress in

Tucker, W. A., H. J. French and, Flow in a low-carbon steel at various temperatures..

Tuckerman, $L$. B., and C. S. Aitchison, Dosign of specimens for short-time "fatigue" tests.

Twist, effect of, on the physical properties of a number $7 \mathrm{~s}$ yarn................................. $\mathrm{V}$

Vegetable, chrome and, tanned sole leathers, comparative durability of

W

Walls, sand-lime brick, compressive strength of Walker, $P$. H., and $E$. F. Hickson, Use of United States Govcrnment specification paints and paint materials ................ Waltenberg, R. G., P. D. Merica and, Malleability and metallography of nickel........Weaver, E. R., Relation between heating value of gas and its usefulness to the consumcr. A critical review of published

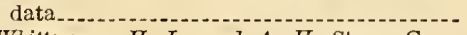
Whittemore, H. L., and A. H. Stang, Compressive strength of sand-lime brick walls.. Wormeley, P. L., W. L. Holt and, Wearing qualities of tire treads as influeneed by reclaimed rubber

- $W . L$. Holt and, Effect of tire resistance

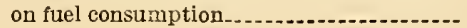

$$
\mathrm{Y}
$$

Yarn, number 7s, effect of twist on the physical properties of a......................... Yarns, rope, a standard bending test for -...-Z

Zobel, Carl G. F, and $L, B$, Carroll, A hotwire anemometer for measuring air flow tlurough engine radiators.
Page 